\title{
Important calixarene derivatives - their synthesis and applications
}

\author{
Gillian McMahon*, Shane O’Malley, Kieran Nolan, and Dermot Diamond \\ National Centre for Sensor Research, Dublin City University, Dublin, Ireland \\ E-mail: gillian.mcmahon@dcu.ie
}

Dedicated to Professor Anthony McKervey on his Retirement
from Queen's University, Belfast, Ireland
(received 05 Mar 03; accepted 24 Mar 03; published on the web 17 Apr 03)

\begin{abstract}
Since their discovery as by-products in the phenol-formaldehyde condensation to prepare bakelites, the calixarenes have gained much attention for their application as both surfactants and chemoreceptors. The McKervey group has been a leader in the development and synthesis of new and novel calixarenes for use as ion-complexing agents as well as for use in many other applications. Many calixarene derivatives prepared by the McKervey group are being used in both environmental and biomedical monitoring. This review covers both the synthesis and sensor applications of the various calixarenes developed by the McKervey group over the past two decades, with emphasis on metal cation detection.
\end{abstract}

Keywords: Calixarene, ion-selective electrode, sensor, synthesis, enatioselective, optodes

\section{Introduction}

The calixarenes are a class of cyclooligomers formed via a phenol-formaldehyde condensation. They exist in a 'cup' like shape with a defined upper and lower rim and a central annulus (see Figure 1). Their rigid conformation enables calixarenes to act as host molecules as a result of their preformed cavities. By functionally modifying either the upper and/or lower rims it is possible to prepare various derivatives with differing selectivities for various guest ions and small molecules. Calixarenes lend themselves well to many applications because of the multiplicity of options for such structural elaboration. 


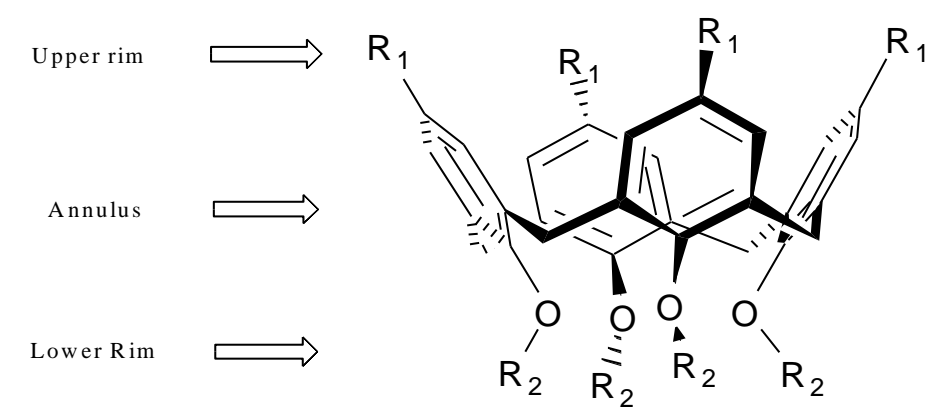

Figure 1. Cone conformation of a typical calix[4]arene.

For calixarenes to be used in ionselective electrode (ISE) and bulk optode sensing devices, they must be immobilised into organic membranes (films/coatings) which are hydrophobic in nature. Furthermore, if aqueous analysis is desired, the calixarenes must be water insoluble otherwise immobilisation would be undermined by water dissolution of the ionophore from the device. It is essential that the calixarenes used in this way be lipophilic with very low water solubility.

McKervey and his group have carried out much research in the synthesis of new types of calixarenes for various applications and some of this important work will be discussed in this paper.

\section{Calixarenes as electrochemical sensors}

The McKervey group began work on calixarene synthesis back in the 1980s. Their first major accomplishment in the field involved the modification of the lower rims of the tetra-, hexa- and octa- calixarenes by the introduction of a series of acetate esters. The calixarene ester derivatives were shown to have characteristics which make them attractive agents for use in potentiometric ion sensors ${ }^{1,2,3,4}$. These simple modifications were achieved in one step (see Scheme 1) and the resulting calixarenes demonstrated outstanding selectivity for various cations. Calixarenes $1 \mathrm{~b}-1 \mathrm{e}$ displayed selectivity toward the sodium cation, with $1 \mathrm{~b}$ being the most efficient. It was reasoned that the presence of the t-butyl groups in the upper rim forced the calixarene into a permanent cone conformation which allowed the esters to form the necessary cavity for coordination. The hexamer esters showed less affinity toward the sodium cation but had affinities for potassium, rubidium and caesium cations. Thus, the formation of a larger cavity allows for more efficient binding of the larger metal cations. The octomer did not demonstrate much binding efficiencey for most of the metal cations tested. 

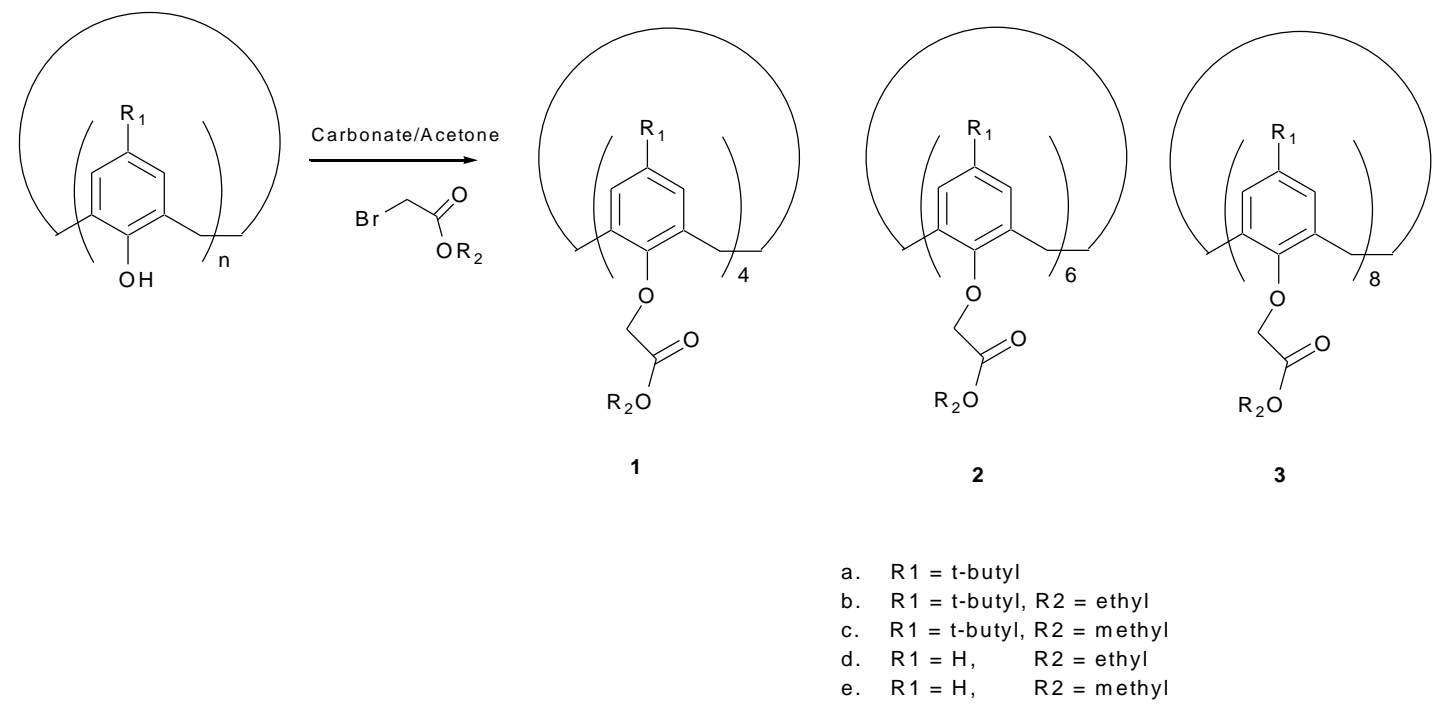

Scheme 1. Preparation of calixarene esters.

\section{Alkali ions}

McKervey and Svelha had realised back in the late 1980s and early 1990s that calixarenes with cation-complexing groups attached to the lower rim would posses the molecular requirements for the type of ionophores used in ISEs ${ }^{1,5}$. Tetramers (4 phenolic units) in the cone conformation have been the most widely used calixarenes for this purpose. Calixarenes with oxygen donor atoms turned out to be suitable for selectively binding alkali ions. Nitrophenol or azophenol moieties on calix[4]arenes equipped with additional ester groups were found to be selective for lithium ${ }^{5}$. Many of these compounds found applications as optical sensors (see Figure 2).

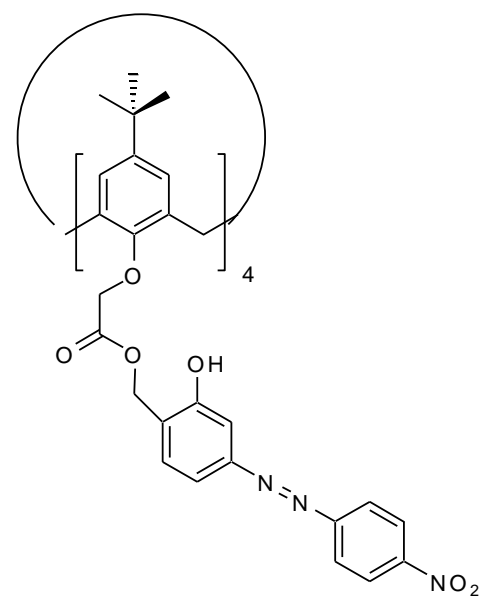

Figure 2. Tetraazophenol calix[4]arenes used in the detection of amines.

The calix[4]arene tetraesters have excellent selectivity for sodium ${ }^{7}$ and McKervey has been very active in this field ${ }^{5,8,9,10,11}$. In 1994, McKervey et al reported on the complexing ability of 19 symmetrical, unsymmetrical and bridged calix[4]arene derivatives having ester, ketone, 
amide, amine and thioether functionalities ${ }^{12}$. Four ionophores in particular gave excellent selectivity and sensitivity and lifetimes of $>200$ days. The calix[4]arene tetra ethyl ester is now available commercially for making sodium selective electrodes ${ }^{13}$. Electrodes of this type are used commonly in hospitals for measuring sodium in blood. McKervey has also developed calixarene derivatives selective for potassium ${ }^{14}$ and caesium ${ }^{15,16}$. In 1996, McKervey reported on the use of a hexameric calixarene for the selective binding of caesium and strontium ${ }^{17}$. This work demonstrated that the introduction of new coordinating functionalities into the lower rim of a calixarene affects the binding affinities for metal cations, and that it is possible to manipulate the various sized cavities to obtain desired selectivities.

Perhaps the next major achievement of the McKervey group in the area of calixarene chemistry was the preparation of the phosphine oxide series of calixarenes ${ }^{18,19,20}$. The synthetic method used to make the phosphine oxides is outlined in Scheme 2. These compounds were initially prepared to investigate the complexation of lanthanide and actinide ions that could be applied in the extraction of radioactive elements from nuclear waste. What was interesting about these compounds was their selectivity for calcium ions (specifically the tetramer 4) when incorporated into ISEs. This ligand was found to selectively bind calcium over magnesium and the alkali metal ions and to last effectively for at least seven weeks.

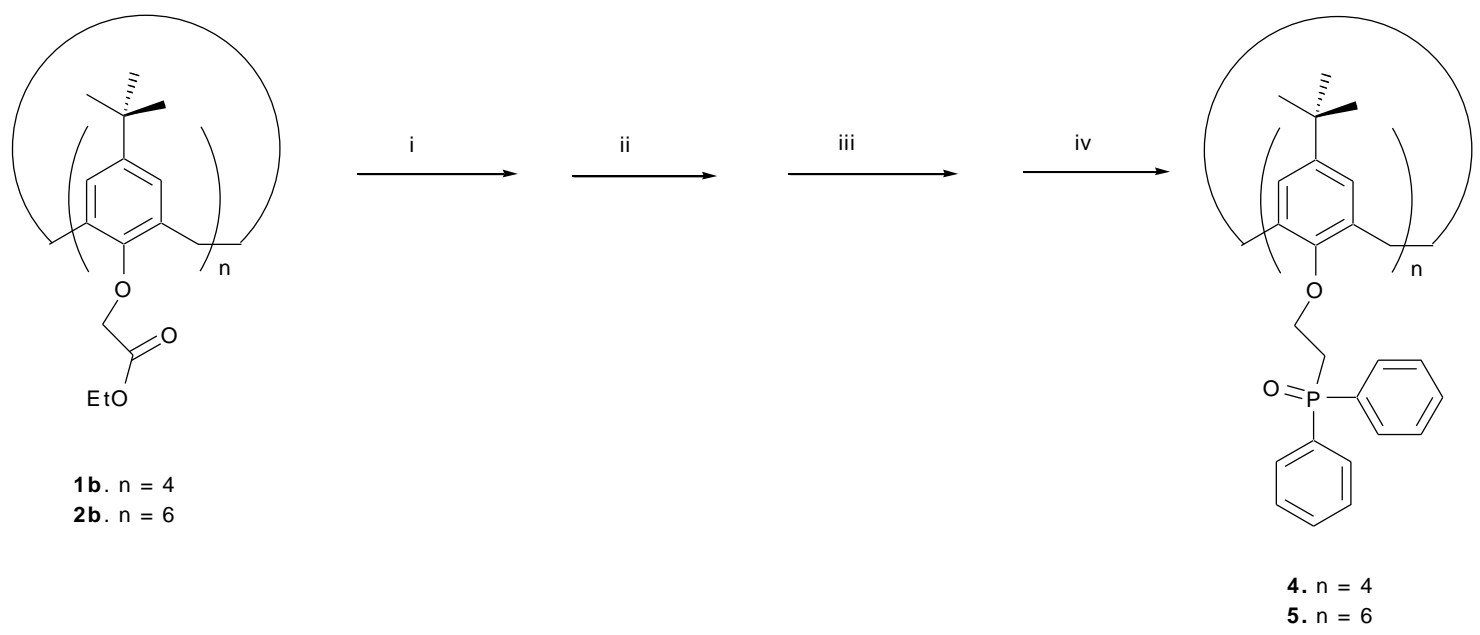

Scheme 2. Synthesis of the phosphine oxide calixarenes. i) DIBAL/THF, ii) tosylCl/pyridine, iii) $\mathrm{PCl}(\mathrm{Ph})_{2} / \mathrm{Na}$, iv) peroxide.

In these, and most other calixarene derivatives, the groups attached to the phenoxy oxygen atoms of the lower-rim are of the same type, and the binding sites are therefore more-or-less evenly distributed in space. The McKervey group continued exploring structural modifications of both the lower and upper rims of the calixarenes and became interested in calix[4]arene derivatives in which the pendent groups are not the same. For example, receptors with the same binding sites attached by different spacer groups at the opposite 1,3 and 2,4 positions would result in a tetrahedral spatial distribution of sites, with different selectivity than the conventional 
tetraesters. The group developed new methods for the preparation of 1,3-disubstituted-tetra-tbutylcalix[4]arenes (see Figure 3) which allowed for the preparation of novel low symmetry calix[4]arenes by the introduction of a different second functionality into the remaining 2,4positions of the lower rim. The development of an efficient synthesis to the 1,3-disubstituted calix[4]arenes opened the door to the development of new and novel chromogenic and fluorogenic receptors by the Shinkai and Kubo groups.

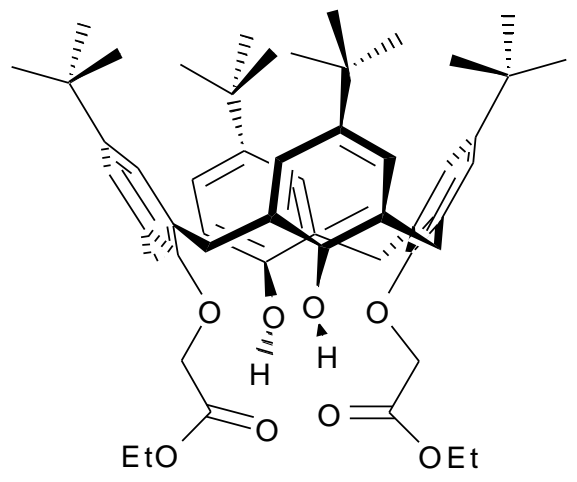

Figure 3. 1,3-disubstituted-tetra-t-butylcalix[4]arene.

\section{Heavy metal ions}

The McKervey tetrameric calixarenes where nitrogen and sulphur were used in the coordination centre were found to be selective for soft heavy metal ions such as silver ${ }^{21,22}$. Since this work, other groups have tried to enhance this binding using further derivatisation ${ }^{23,24}$. Electrodes based on the hexamer derivative (calixarene 5) of the phosphine oxide series of derivatives (see Scheme 2) were found to have excellent selectivity for lead ions ${ }^{25}$. McKervey has also published in the area of mercury, lead and copper ion recognition by anodic stripping voltammetry using thioamide groups on a calixarene sleleton ${ }^{26,27}$.

\section{Calixarenes as optical sensors}

Optical transduction based sensors have been extensively investigated since the late 1980's. The optical transduction technique is an attractive alternative to electrochemical methods since there is less noise pickup in signal transmission over long distances, and it is possible to analyse the full spectrum with one probe instead of just one channel of electrochemical information as is the case with electrochemical devices. The theoretical principles of optical sensors are very similar to those used to define ISEs and membranes of similar (quite often identical) composition to that of ISE membranes are used in optical sensors. The requirement for optical sensors to work is that an optically responsive mechanism must be coupled to the ion-ligand complexation process e.g. immobilising a dye (chromoionophore) in the membrane with the ligand. An advantage is that there is no modification made to the ligand. The chromoionophore is usually an acid base indicator and interacts with a reference ion which is normally a proton. The original selectivity is usually observed although the $\mathrm{pH}$ of the dye can sometimes cause problems. Thus if sample $\mathrm{pH}$ 
is known (this value can be controlled by buffer) then the activity of the analyte ion can simply be determined by an absorbance change in the sensor membrane. This class of optical sensor is quite often referred to as a bulk optode. Alternatively, dyes can be attached directly to the calixarene ${ }^{28,29}$. McKervey has been involved in the development of novel chromogenic calixarene-based ligands for the optical detection of alkali ions ${ }^{6,30,31}$ and has worked on the use of calixarenes as optical sensors for gaseous ammonia detection in fish samples ${ }^{32}$. The optical detector was based on a calix[4]arene to which a nitrophenylazophenol chromophore is attached. A shift occurs in the electronic spectrum when coordination of a specific metal ion takes place.

A propranolol amide derivative of p-allyl calix[4] arene was designed to behave as an optical chiral sensor for distinguishing amines on the basis of their shape and chirality ${ }^{33}$. This molecule can discriminate between the enantiomers of phenylalaninol through the quenching of the fluorescence emission in methanol.

\section{Calixarenes as chiral recognition devices}

One of the great problems faced by the pharmaceutical industry involves the quantitation of undesirable enantiomers in drug raw material. Quite often only one enantiomer of a chiral compound is actually a bioactive therapeutic. It is therefore essential that final product be properly analysed for enantiomeric purity. Currently, this analysis involves chromatographic methods based on chiral phase separations. Sensing devices, which can differentiate between different enantiomers, would be a cheaper, easier way of carrying out this work.

The McKervey group in colaboration with the Diamond group have been involved in studies carried out with (S)-di-napthylprolinolcalix[4]arene which has shown excellent chiral discrimination between the enantiomers of phenylglycinol, phenylethylamine and norephedrine 34. The mechanism of transduction in this example is based on the fluorescence quenching of the napthylprolinol handles of the calixarene upon comlpexation with the R-enatiomer of phenylglycinol. This calixarene has been successfully immobilised on a capillary wall used in capillary electrophoresis showing very good resolution in the separation of the enatiomers of phenylglycino ${ }^{35}$. More recently, a fluorogenic calixarene derivative containing propranolol moities on the lower rim, was capable of discriminating between the enantiomers of phenylalaninol ${ }^{33}$ (see Figure 4). It was also found that a significant enhancement in the observed enantiomeric discrimination would occur on binding of the calixarene with potassium cation. 


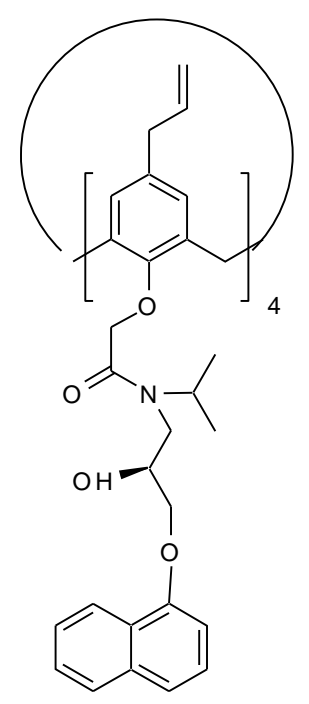

Figure 4. Propranolol amide derivative of $p$-allylcalix[4]arene.

\section{Calixarenes as solid phase extraction phases}

McKervey has reported on the use of a calixarene hydroxamate derivative as a solid phase extraction phase ${ }^{36}$. The trace enrichment of copper, zinc and manganese from water samples prior to ion chromatographic analysis was demonstrated.

\section{Calixarenes as stationary phases}

The chromatographic selectivity of silica bonded calix[4]arene tetraester stationary phases for amino acid esters and alkali metal ions has led to McKervey using calixarenes as stationary phases ${ }^{37}$. Brindle et al characterised silica-bonded calixarene phases using ${ }^{29} \mathrm{Si}$ and ${ }^{13} \mathrm{C}$ solidstate NMR. This characterisation method provided direct evidence for the attachment of the macrocyclic calixarenes to the silica ${ }^{38}$.

\section{Calixarenes as modifiers}

McKervey and his group have been involved in chromatographic studies involving the use of water-soluble sulphonated calixarenes in mobile phases to determine nitrophenol compounds by HPLC ${ }^{39}$. Sulphonated calixarenes are capable of forming host-guest complexes with various cations and hence the selectivity of the separation is increased.

\section{References}

1. Diamond, D.; McKervey, M.A. Chem. Soc. Rev. 1996, 15.

2. Forster, R.J.; Cadogan, A.; Diaz, M. T.; Diamond, D.; Harris, S.; McKervey, M.A., Calixarenes as active agents for chemical sensors, Sensors and Actuators B: Chemical 1991, 4(3-4), 325. 
3. Diamond, D.; Nolan, K., Calixarenes: designer ligands for chemical sensors, Anal. Chem. 2001, 73(1), 22-29A.

4. Cadogan, F.; Nolan, K.; Diamond, D. In Calixarenes 2001 Asfari, Z.; Bohmer, V.; Harrowfield, J.; Vicens, J., Eds; Kluwer Academic Press: Dordrecht, The Netherlands, 2001; Ch. 34, pp 627-641.

5. Diamond, D.; Svehla, G.; Seward, E.M.; McKervey, M.A., A sodium ion-selective electrode based on p-t-butylcalix[4] aryl acetate as the ionophore, Anal. Chim. Acta 1988, 204, 223.

6. McCarrick, M.; Wu, B.; Harris, S.J.; Diamond, D.; Barrett, G.; McKervey, M.A., Novel chromogenic ligands for lithium and sodium based on calix[4]arene tetraesters, J. Chem. Soc Chem. Commun. 1992, 1287.

7. Forster, R.; Diamond, D. Anal. Chem. 1992, 64(15), 1721.

8. Cadogan, A.; Diamond, D.; Smyth, M.R.; Deasy, M.; McKervey, M.A.; Harris, S.J. Analyst 1989, 114, 1551.

9. Cunnigham, K.; Svelha, G.; McKervey, M.A.; Harris, S.J. Anal Proc. 1991, 28, 294.

10. Cunnigham, K.; Svelha, G.; Harris, S.J.; McKervey, M.A. Analyst 1993, 118(4), 341.

11. Gradny, T.; Cadogan, A.; McKittrick, T.; Harris, S.J.; Diamond, D.; McKervey, M.A., Sodium-selective electrodes based on triester monoacid derivatives of p-tertbutylcalix[4]arene. Comparison with tetraester calyx[4]arene ionophores, Anal. Chim. Acta 1996, 336(1-3), 1.

12. O’Connor, K. M.; Cherry, M.; Svehla, G.; Harris, S.J.; McKervey, M.A., Symmetrical, unsymmetrical and bridged calyx[4]arene derivatives as neutral carrier ionophores in PVC membrane sodium selective electrodes, Talanta 1994, 41(7), 1207.

13. See for example the calix[4]arene tetraethyl ester described as 'sodium ionophore $X$ ', available from Fluka, Product Number: 71747, CAS: 97600-39-0, MDL Number: MFCD00145373.

14. Cadogan, A.; Diamond, D.; Cremin, S.; McKervey, M.A.; Harris, S.J. Anal Proc. 1991, $28,13$.

15. Cadogan, A.; Diamond, D.; Smyth, M.R.; Svehla, G.; McKervey, M.A.; Seward, E. M.; Harris, S.J., Caesium-selective poly(vinyl chloride) membrane electrodes based on calyx[6]arene esters, Analyst 1990, 115, 1207.

16. Brunink, J.; Haak, J.R.; Bomer, J.G.; Reinhoudt, D.N.; McKervey, M.A.; Harris, S.J. Anal. Chim. Acta 1991, 254, 75.

17. Fanni, S.; Arnaud-Neu, F.; McKervey, M.A.; Schwing-Weill, M.J.; Ziat, K., Dramatic effects of p-dealkylation on the binding abilities of p-tert-butylcalix[6]arenes: new $\mathrm{Cs}^{+}$and $\mathrm{Sr}^{2+}$ selective receptors, Tetrahedron Letts. 1996, 37(44), 7975.

18. Arnaud-Neu, F.; Barrett, G.; Fanni, S.; Marrs, D.; McGregor, W.; McKervey, M.A.; Schwing-Weill, M.J.; Vetrogon, V.; Wechsler, S., Extraction and solution thermodynamics of complexation of alkali and alkaline earth cations by calix[4]arene amides, J. Chem. Soc. Perkin Trans. II 1995, 453.

19. McKittrick, T.; Diamond, D.; Marrs, D. J.; O’Hagan, P.; McKervey, M.A., Calcium-selective electrode based on a calix[4]arene tetraphosphine oxide, Talanta 1996, 43(7), 1145. 
20. Kane, P.; Fayne, D.; Diamond, D.; McKervey, M.A. J. Mol. Mod. 2000, 6, 272.

21. O’Connor, K. M.; Svehla, G.; Harris, S. J.; McKervey, M.A., Calixarene-based potentiometric ion-selective electrodes for silver, Talanta 1992, 39(11), 1549.

22. O’Connor, K. M.; Svehla, G.; Harris, S. J.; McKervey, M.A., Anal. Proc. 1993, 30, 137.

23. Zeng, X.; Weng, L.; Chen, L.; Leng, X.; Zhang, Z.; He, X. Tetr. Letts. 2000, $41(25), 4917$.

24. Chen, L.; Zeng, X.; Ju, H.; He, X.; Zhang, Z. MicroChemical Journal, 2000, 65(2), 129.

25. Cadogan, F.; Kane, P.; McKervey, M.A.; Diamond, D., Lead-selective electrodes based on calixarene phosphine oxide derivatives, Anal. Chem. 1999, 71(24), 5544.

26. Arrigan, D.W.M.; Svehla, G.; Harris, S.J.; McKervey, M.A., Use of calixarenes as modifiers of carbon paste electrodes for voltammetric analysis, Electroanalysis 1994, 6, 97.

27. Arrigan, D.W.M.; Svehla, G.; Harris, S.J.; McKervey, M.A., Stripping voltammetry with a polymeric calixarene modified carbon paste electrode, Anal. Proc. 1992, 29, 27.

28. Loughran, M.; Diamond, D., Monitoring of volatile bases in fish sample headspace using an acidochromic dye, Food Chemistry 2000, 69(1), 97.

29. Kubinyi, M.; Mohammed-Ziegler, I.; Grofcsik, A.; Bitter, I.; Jones, W. J., Spectroscopic study of complex formation between alkali metal ions and chromogenic calixarene derivatives, Journal of Molecular Structure 1997, 408-409, 543.

30. McCarrick, M.; Harris, S.J.; Diamond, D.; Barrett, G.; McKervey, M.A., Assessment of three azophenol calix[4]arenas as chromogenic ligands for optical detection of alkali metal ions, Analyst 1993, 118, 1127.

31. McCarrick, M.; Wu, B.; Harris, S.J.; Diamond, D.; Barrett, G.; McKervey, M.A., Chromogenic ligands for lithium based on calix[4]arene tetraesters bearing nitrophenol residues, J. Chem. Soc. Perkin Trans. II 1993, 1963.

32. Grady, T.; Butler, T.; MacCraith, B.D.; Diamond, D.; McKervey, M.A., Optical sensor for gaseous ammonia with tunable sensitivity, Analyst 1997, 122(8), 803.

33. Lynam, C.; Jennings, K.; Nolan, K.; Kane, P.; McKervey, M.A.; Diamond, D. Tuning and enhancing enantioselective quenching of calixarene hosts by chiral guest amines, Anal. Chem. 2002, 74(1), 59.

34. Grady, T.; Harris, S.J.; Smyth, M.R.; Diamond, D. Anal. Chem. 1996, 68, 3775.

35. Grady, T.; Joyce, T.; Smyth, M.R.; Harris, S.J.; Diamond, D., Chiral resolution of the enantiomers of phenylglycinol using S-di-naphthylprolinol calix[4]arene by capillary electrophoresis and fluorescence spectroscopy, Anal. Comm. 1998, 35(4), 123.

36. Hutchinson, S.; Kearney, G.A.; Horne, E.; Lynch, B.; Glennon, J.D.; McKervey, M.A.; Harris, S.J. Solid phase extraction of metal ions using immobilized chelating calixarene tetrahydroxamates, Anal. Chim. Acta 1994, 291(3), 269.

37. Glennon, J.D.; Horne, E.; O’Connor, K.; Kearney, G.A.; Harris, S.J.; McKervey, M.A. Anal Proc. 1994, 31, 33.

38. Brindle, R.; Albert, K.; Harris, S.J.; Troltzsch, C.; Horne, E.; Glennon, J. D. J. Chrom. A 1996, 731, 41.

39. Millership, J.S.; McKervey, M.A.; Russell, J.A., Complexation and chromatographic studies involving water-soluble calixarenes and nitrophenols, Chromatographia 1998, 48(5-6), 402. 